\title{
THE OVIDUCT AND DEVELOPMENT OF THE PREIMPLANTATION EMBRYO
}

\author{
WSB YEUNG, CKF LEE AND JS XU \\ Department of Obstetrics and Gynaecology, University of Hong Kong, Queen Mary Hospital, \\ Hong Kong, China
}

\section{INTRODUCTION}

Fertilization and early embryo development take place in the oviduct in vivo. Relative to studies in other reproductive organs, the importance of the oviduct has been ignored for many years because pregnancies can be obtained in assisted reproduction treatment using in-vitro fertilization (IVF) and embryo transfer to the uterus without involving the Fallopian tube. After the reports on the beneficial effect of oviductal cells on embryo development in sheep ${ }^{1}$ and subsequently in human, ${ }^{2}$ and a practical need to improve the success rates in clinical assisted reproduction, there was a period when more research was performed on the Fallopian tube. Many of these studies used in vitro coculture systems to emulate the in vivo environment in vitro, and to search for oviduct-derived embryotrophic factors. With the recent development of sequential culture $^{3}$ to improve embryo development in vitro, the use of coculture in assisted reproduction and its related research declined because routine use of coculture is laborious and experience-dependent.

Despite this, evidence is now accumulating to suggest that this organ is not a passive conduit for gametes and embryos. Before fertilization, it is well accepted that the oviduct serves as a sperm reservoir in several animal species. ${ }^{4,5}$ Although there is no direct evidence for such a function in human Fallopian tube in vivo, in vitro experiments have demonstrated that human spermatozoa bind to the tubal epithelial cells. ${ }^{6}$ In addition, human oviductal cells affect sperm functions in vitro. ${ }^{7-9}$ After fertilization, the oviduct provides the microenvironment for early embryonic development. This review intends to provide an update on this postfertilization role of the oviduct, with a particular emphasis on human reproduction.

There is only limited evidence to show which of the oviductal changes are important for embryonic development because it is difficult to change each of these parameters independent of the others in vivo and to study the effect of such changes on embryo development. Moreover, the effect of the oviduct on embryo development

Address for correspondence: WSB Yeung, Department of Obstetrics and Gynaecology, The University of Hong Kong, Queen Mary Hospital, Pokfulam Road, Hong Kong, China;

Tel.: +852-285-53405; Fax: +852-2855-0947, e-mail: wsbyeung@hkucc.hku.hk. 
Table 1 Expression of growth factors/cytokines and their receptors in human Fallopian tube and embryos

\begin{tabular}{|c|c|c|c|c|c|c|c|}
\hline $\begin{array}{l}\text { Growth factor/ } \\
\text { cytokines \& } \\
\text { receptors }\end{array}$ & Oviduct & Oocyte stage & 2-cell stage & $\begin{array}{l}3 \text { - to } 4 \text {-cell } \\
\text { stage }\end{array}$ & $\begin{array}{l}6 \text { - to } 8 \text {-cell } \\
\text { stage }\end{array}$ & Morula & Blastocyst \\
\hline IGF1 & $+t^{21}, p^{19,21,94}$ & $-t^{20}$ & $-t^{20}$ & $-t^{144}$ & $-t^{20,144}$ & & $-t^{20,144}$ \\
\hline IGF2 & $+p^{19}$ & $+\mathrm{t}^{20}$ & $+\mathrm{t}^{20}$ & & $+t^{20,144}, p^{18}$ & $+p^{18}$ & $+t^{20,144}, p^{18,18}$ \\
\hline Insulin R & & $+\mathrm{t}^{20}$ & $-t^{20}$ & & $+\mathrm{t}^{20,144}$ & & $+t^{20,144}$ \\
\hline IGF1 R & $+p^{19,94}$ & $+\mathrm{t}^{20}$ & $+\mathrm{t}^{20}$ & & $+\mathrm{t}^{20}$ & & $+\mathrm{t}^{20}, \mathrm{p}^{21}$ \\
\hline IGF2 R & $+p^{19}$ & $+\mathrm{t}^{20}$ & $+t^{20}$ & & $+t^{20}$ & & $+t^{20}$ \\
\hline IGFBP-1 & $\mathrm{pt}^{145} ;+\mathrm{p}^{94}$ & & & $-t^{144}$ & & & $\begin{array}{l}t \\
+t^{144}\end{array}$ \\
\hline IGFBP-2 & $+\mathrm{t}^{145}, \mathrm{p}^{94,145}$ & & & & $+t^{144}$ & & $+t^{144}$ \\
\hline IGFBP-3 & $+t^{145}, p^{94,145}$ & & & & $+t^{144}$ & & $+t^{144}$ \\
\hline IGFBP-4 & $+\mathrm{t}^{145}, \mathrm{p}^{94}$ & & & & $+t^{144}$ & & $+t^{144}$ \\
\hline IGFBP-5 & & & & $-t^{144}$ & $+t^{144}$ & & $+t^{144}$ \\
\hline IGFBP-6 & & & & $-t^{144}$ & $-t^{144}$ & & $-t^{144}$ \\
\hline TGF $\beta$ & $+t^{146}, p^{146}$ & & & $+p^{147}$ & & & \\
\hline TGF $\beta$-RI & & $+t^{148}, p^{148}$ & & $-t^{148}$ & $-t^{148}$ & $-t^{148}$ & $+t^{148}$ \\
\hline TGF $\beta$-RII & $+t^{146}, p^{146}$ & $+t^{148}, p^{148}$ & & $-t^{148}$ & $-\mathrm{t}^{148}$ & $-\mathrm{t}^{148}$ & $-t^{148}$ \\
\hline Smad2/3 & & $+\mathrm{t}^{148}, \mathrm{p}^{148}$ & & $+\mathrm{t}^{148}$ & $+\mathrm{t}^{148}$ & $+\mathrm{t}^{148}$ & $+\mathrm{t}^{148}$ \\
\hline Inhibin $\alpha$ & $-p^{149}$ & & $-t^{150}$ & $-t^{150}$ & $-t^{150}$ & $-t^{150}$ & $-t^{150}$ \\
\hline Activin & $+\mathrm{t}^{150}, \mathrm{p}^{150}$ & & $-t^{150}$ & $-t^{150}$ & $-t^{150}$ & $-t^{150}$ & $+t^{150}$ \\
\hline Activin IR & & & $-t^{150}$ & $+t^{150}$ & $-t^{150}$ & $-t^{150}$ & $+\mathrm{t}^{150}$ \\
\hline Activin IIR & & & $+t^{150}$ & $+t^{150}$ & $+t^{150}$ & $+t^{150}$ & $+\mathrm{t}^{150}$ \\
\hline Follistatin & & & $-t^{150}$ & $-t^{150}$ & $+t^{150}$ & $+t^{150}$ & $\begin{array}{l}+\mathrm{t} \\
+\mathrm{t}^{150}\end{array}$ \\
\hline TGF- $\alpha$ & $+\mathrm{t}^{14,15,74,151}, \mathrm{p}^{14-16,151-153}$ & $+t^{154}, p^{154}$ & & $+p^{16}$ & $+t^{154}, p^{16,154}$ & & $+t^{154}, p^{18,18,154}$ \\
\hline EGF & $+t^{14,15,74,107,151,153}, p^{14,15,151,153}$ & $+t^{154}, p^{154}$ & $+\mathrm{t}^{154}, \mathrm{p}^{154}$ & & $+t^{154}, p^{154}$ & & \\
\hline EGF-R & $+t^{17,74,151,153}, p^{16,17,151}$ & & $+p^{16}$ & $+p^{16}$ & & & \\
\hline GM-CSF & $+t^{90}, p$ & & & & & & \\
\hline GM-CSF-R & $+t^{90}$ & & & & & & \\
\hline VEGF & & & & & & & $+t^{155}$ \\
\hline
\end{tabular}




\begin{tabular}{|c|c|c|c|c|c|c|c|}
\hline \multirow{2}{*}{\multicolumn{2}{|c|}{$\begin{array}{l}\text { PDGF- } \alpha \text { and }-\beta \\
\text { PDGFR- } \alpha \text { and }-\beta\end{array}$}} & \multicolumn{2}{|l|}{$+t^{156}$} & $-t^{156}$ & $+t^{156}$ & $+t^{156}$ & $+t^{156}$ \\
\hline & & $-t^{156}$ & & $+t^{156}$ & $+t^{156}$ & $-t^{156}$ & $+\mathrm{t}^{156}$ \\
\hline $\mathrm{IL}-1 \alpha$ & $+p^{157}$ & & & $+p^{147,158}$ & & & \\
\hline $\mathrm{IL}-1 \beta$ & $+p^{159}$ & $+t^{160}, p^{161}$ & & $+t^{160}, p^{161,161}$ & $+\mathrm{t},{ }^{160}, \mathrm{p}^{161}$ & $+t^{160}, p^{161}$ & $+t^{160}, p^{161}$ \\
\hline IL-1R tI & & $+t^{160}, p^{161}$ & & $+\mathrm{t}^{160}, \mathrm{p}^{161}$ & $+\mathrm{t}^{160}, \mathrm{p}^{161}$ & $-t^{160} \cdot p^{161}$ & $+\mathrm{t}^{160} \cdot \mathrm{p}^{161}$ \\
\hline IL-1ra & $+p^{159}$ & $+t^{160}, p^{161}$ & & $+t^{160}, p^{161}$ & $+t^{160}, p^{161}$ & $+t^{160}, p^{161}$ & $+t^{160}, p^{161}$ \\
\hline CSF & $+\mathrm{t}^{107}$ & & $-t^{162}, p^{163}$ & $-t^{162}, p^{163}$ & $-t^{162}, p^{163}$ & $-t^{162}$ & $-t^{162}$ \\
\hline CSF R & & & $-t^{162}$ & $-t^{162}$ & $-t^{162}$ & $-t^{162}$ & $-t^{162}$ \\
\hline LIF & $+t^{107}, p^{159}$ & & $-t^{162}$ & $-t^{162}$ & $-t^{162}$ & $-t^{162}$ & $-t^{162}$ \\
\hline LIF-R & & $+t^{164}$ & $-t^{162}$ & $-t^{162}$ & $-t^{162}$ & $-t^{162}$ & $+\mathrm{t}^{162,164,165}$ \\
\hline & & & $+t^{164}$ & $+t^{164}$ & $+t^{164}$ & & \\
\hline IL-6 & $+t^{107}$ & $+p^{163}$ & $+\mathrm{p}^{163}$ & $+p^{147,163}$ & & & $+t^{162}$ \\
\hline IL-6R & & & & & & & $+t^{162}$ \\
\hline c-fms & & & $+t^{162}$ & $+\mathrm{t}^{162}$ & $+\mathrm{t}^{162}$ & $-t^{162}$ & $+\mathrm{t}^{162}$ \\
\hline TNF-R p80 & & & $+t^{162}$ & $+t^{162}$ & $-t^{162}$ & $-t^{162}$ & $-t^{162}$ \\
\hline TNF-R p60 & & & $-t^{162}$ & $-t^{162}$ & $+t^{162}$ & $-t^{162}$ & $+t^{162}$ \\
\hline TNF- $\alpha$ & $+p^{159}$ & & $-t^{162}$ & $+t^{162}$ & $-t^{162}, p^{163}$ & $+t^{162}$ & $-t^{162}$ \\
\hline c-kit & & & $+t^{162}$ & $+\mathrm{t}^{162}$ & $+t^{162}$ & $-t^{162}$ & $+t^{162}$ \\
\hline SCF & & & $+\mathrm{t}^{162}$ & $-t^{162}$ & $+\mathrm{t}^{162}$ & $+t^{162}$ & $-t^{162}$ \\
\hline gp130 & & $+t^{164}$ & $-t^{162}$ & $+t^{162}$ & $-t^{162}$ & $+t^{162}$ & $+t^{162}$ \\
\hline
\end{tabular}

t, transcript; p, protein; +, detectable; -, undetectable; ?, barely detectable; blank space, no information available.

IGF, insulin-like growth factor; R, receptor; IGFBP, insulin-like growth factor binding protein; TGF, transforming growth factor; EGF, epidermal growth factor: GM-CSF, granulocyte-macrophage colony-stimulating factor; VEGF, vascular endothelial growth factor; PDGF, platelet-derived growth factor;

IL, interleukin; IL-1ra, Interleukin-1 receptor antagonist; CSF, colony stimulating factor; LIF, leukaemia inhibitory factor; c-fms, colony stimulating factor receptor; TNF, tumor necrosis factor; c-kit, stem cell factor receptor; SCF, stem cell factor; gp130, a component of LIF and IL-6 receptor.

Reference numbers are shown in superscript. 
is facilitatory and not obligatory, making the detection of oviductal embryotrophic effects more difficult. Nevertheless, there is circumstantial evidence mainly from animal studies showing that the oviduct plays a fundamental role in early embryo development. This evidence is reviewed below.

\section{CYCLICAL CHANGE OF OVIDUCTAL ACTIVITY}

Changes in the ciliated and secretory cells of the primate oviduct are well documented across the reproductive cycle. ${ }^{10}$ These changes are regulated by steroids, such that estrogen induces hypertrophy, maturation and an increase in cell height of nonciliated secretory oviductal epithelial cells and can partially restore ciliated phenotype in vitro. ${ }^{11}$ These, together with cyclical morphological and physiological variations in the uterus, suggest that these two organs are actively involved in early reproductive events, and that they offer a dynamic microenvironment for the development of preimplantation embryos.

The presence of growth factors in the oviduct and the corresponding receptors in the preimplantation embryo or vice versa suggests possible mechanisms of interaction between the oviduct and the embryo. The expression of growth factors in the preimplantation embryo and oviduct has recently been reviewed. ${ }^{12,13}$ Table 1 updates their occurrence in human oviduct and preimplantation embryos at protein and mRNA levels. Many of the growth factors in the oviduct are produced in a cyclical manner. Epidermal growth factor (EGF)/transforming growth factor- $\alpha$ (TGF- $\alpha$ ) and their receptors have been extensively studied in the Fallopian tube and human embryo. The mRNA and protein expression of EGF and TGF- $\alpha$ are intense in the ampullary epithelium at late follicular and luteal stages but weak at the early follicular stage. ${ }^{14,15}$ Their receptor (EGFR) at the protein level is present in 8- to 14cell embryos. ${ }^{16}$ On the other hand, EGFR is also found in the Fallopian tube with an expression pattern similar to its ligands. ${ }^{17}$ Human embryos also secrete TGF- $\alpha$ into the culture medium; the secretion increases as the embryos develop to morula and blastocyst. ${ }^{18}$ A similar situation exists for the insulin-like growth factor (IGF) system, with expression of the ligand and receptor found in both the Fallopian tube and the early embryo. ${ }^{16,19,20}$ Although the addition of some of these factors stimulates embryo development in vitro, ${ }^{21}$ it is uncertain whether these signaling systems are performing paracrine and/or autocrine function in vivo.

\section{OVIDUCTAL MICROENVIRONMENT AND EMBRYO DEVELOPMENT}

It is generally accepted that the oviduct may have evolved to provide an optimum microenvironment for early embryo development. An early preimplantation embryo is bathed in oviductal fluid. Therefore, knowledge on the content of the oviductal fluid is important. The composition of oviductal fluid has been reported in many animal species. Interested readers are referred to reviews by Leese, ${ }^{22}$ Hamner and 
The oviduct and development of the preimplantation embryo

Table 2 Reported composition of oviductal fluids in human and primates

\begin{tabular}{|c|c|c|c|c|}
\hline Components & Species & Cycle & Concentration & Reference \\
\hline \multirow[t]{5}{*}{ Glucose } & \multirow[t]{5}{*}{ Human } & Follicular & $3.11 \mathrm{mM}$ & 36 \\
\hline & & Midcycle & $0.50 \mathrm{mM}$ & \\
\hline & & Luteal & $2.32 \mathrm{mM}$ & \\
\hline & & Different stages & $1.1 \mathrm{mM}$ & 166 \\
\hline & & Different stages & $0.53 \mathrm{mM}$ & 167 \\
\hline \multirow[t]{3}{*}{ Pyruvate } & \multirow[t]{3}{*}{ Human } & Different stages & $0.24 \mathrm{mM}$ & 36 \\
\hline & & Different stages & $0.14 \mathrm{mM}$ & 166 \\
\hline & & Different stages & $0.17 \mathrm{mM}$ & 167 \\
\hline \multirow[t]{5}{*}{ Lactate } & \multirow[t]{5}{*}{ Human } & Follicular & $4.87 \mathrm{mM}$ & 36 \\
\hline & & Midcycle & $10.50 \mathrm{mM}$ & \\
\hline & & Luteal & $6.19 \mathrm{mM}$ & \\
\hline & & All stages & $5.85 \mathrm{mM}$ & 166 \\
\hline & & All stages & $8.58 \mathrm{mM}$ & 167 \\
\hline \multirow[t]{2}{*}{ Aspartic acid } & \multirow[t]{2}{*}{ Human } & Proliferative & $17 \mu \mathrm{M}$ & 166 \\
\hline & & Secretory & $41 \mu \mathrm{M}$ & \\
\hline \multirow[t]{2}{*}{ Glutamic acid } & \multirow[t]{2}{*}{ Human } & Proliferative & $71 \mu \mathrm{M}$ & 166 \\
\hline & & Secretory & $111 \mu \mathrm{M}$ & \\
\hline \multirow[t]{2}{*}{ Asparagine } & \multirow[t]{2}{*}{ Human } & Proliferative & $63 \mu \mathrm{M}$ & 166 \\
\hline & & Secretory & $28 \mu \mathrm{M}$ & \\
\hline \multirow[t]{2}{*}{ Serine } & \multirow[t]{2}{*}{ Human } & Proliferative & $26 \mu \mathrm{M}$ & 166 \\
\hline & & Secretory & $38 \mu \mathrm{M}$ & \\
\hline \multirow[t]{2}{*}{ Glutamine } & \multirow[t]{2}{*}{ Human } & Proliferative & $24 \mu \mathrm{M}$ & 166 \\
\hline & & Secretory & $51 \mu \mathrm{M}$ & \\
\hline \multirow[t]{2}{*}{ Arginine } & \multirow[t]{2}{*}{ Human } & Proliferative & $151 \mu \mathrm{M}$ & 166 \\
\hline & & Secretory & $237 \mu \mathrm{M}$ & \\
\hline \multirow[t]{2}{*}{ Glycine } & \multirow[t]{2}{*}{ Human } & Proliferative & $32 \mu \mathrm{M}$ & 166 \\
\hline & & Secretory & $37 \mu \mathrm{M}$ & \\
\hline \multirow[t]{2}{*}{ Threonine } & Human & Proliferative & $44 \mu \mathrm{M}$ & 166 \\
\hline & & Secretory & $47 \mu \mathrm{M}$ & \\
\hline Alanine & Human & Proliferative & $84 \mu \mathrm{M}$ & 166 \\
\hline & & Secretory & $139 \mu \mathrm{M}$ & \\
\hline Tyrosine & Human & Proliferative & $24 \mu \mathrm{M}$ & 166 \\
\hline & & Secretory & $49 \mu \mathrm{M}$ & \\
\hline Tryptophan & Human & Proliferative & $12 \mu \mathrm{M}$ & 166 \\
\hline & & Secretory & $18 \mu \mathrm{M}$ & \\
\hline Methionine & Human & Proliferative & $12 \mu \mathrm{M}$ & 166 \\
\hline & & Secretory & $14 \mu \mathrm{M}$ & \\
\hline Valine & Human & Proliferative & $22 \mu \mathrm{M}$ & 166 \\
\hline & & Secretory & $32 \mu \mathrm{M}$ & \\
\hline Phenylalanine & Human & Proliferative & $16 \mu \mathrm{M}$ & 166 \\
\hline & & Secretory & $18 \mu \mathrm{M}$ & \\
\hline Isoleucine & Human & Proliferative & $17 \mu \mathrm{M}$ & 166 \\
\hline & & Secretory & $20 \mu \mathrm{M}$ & \\
\hline Leucine & Human & Proliferative & $50 \mu \mathrm{M}$ & 166 \\
\hline & & Secretory & $67 \mu \mathrm{M}$ & \\
\hline Lysine & Human & Proliferative & $42 \mu \mathrm{M}$ & 166 \\
\hline & & Secretory & $61 \mu \mathrm{M}$ & \\
\hline Sodium & Human & Preovulatory & 140-142 mM & 26,27 \\
\hline & & Postovulatory & $139-148 \mathrm{mM}$ & 26,27 \\
\hline & & Different stages & $130 \mathrm{mM}$ & 168 \\
\hline
\end{tabular}


WSB Yeung, CKF Lee and JS Xu

Table 2 continued

\begin{tabular}{|c|c|c|c|c|}
\hline Components & Species & Cycle & Concentration & Reference \\
\hline \multirow[t]{3}{*}{ Chloride } & \multirow{3}{*}{ Human } & Preovulatory & $119-127 \mathrm{mM}$ & 26,27 \\
\hline & & Postovulatory & $112-117 \mathrm{mM}$ & 26,27 \\
\hline & & Different stages & $132 \mathrm{mM}$ & 168 \\
\hline \multirow[t]{3}{*}{ Potassium } & \multirow[t]{3}{*}{ Human } & Preovulatory & $6.7-9.9 \mathrm{mM}$ & 26,27 \\
\hline & & Postovulatory & $6.7-7.7 \mathrm{mM}$ & 26,27 \\
\hline & & Different stages & $21.2 \mathrm{mM}$ & 168 \\
\hline \multirow[t]{3}{*}{ Calcium } & \multirow[t]{3}{*}{ Human } & Preovulatory & $1.89 \mathrm{mM}$ & 26 \\
\hline & & Postovulatory & $2.37 \mathrm{mM}$ & 26 \\
\hline & & Different stages & $1.13 \mathrm{mM}$ & 168 \\
\hline \multirow{2}{*}{ Magnesium } & \multirow{2}{*}{ Human } & Preovulatory & $0.53-0.69 \mathrm{mM}$ & 26 \\
\hline & & Different stages & $1.42 \mathrm{mM}$ & 168 \\
\hline \multirow[t]{2}{*}{$\mathrm{pH}$} & \multirow[t]{2}{*}{ Rhesus monkey } & Follicular & $7.1-7.3$ & 28 \\
\hline & & Ovulation \& luteal & $7.5-7.8$ & \\
\hline \multirow[t]{2}{*}{ Bicarbonate } & \multirow[t]{2}{*}{ Rhesus monkey } & Follicular & $35 \mathrm{mM}$ & 28 \\
\hline & & Luteal & $90 \mathrm{mM}$ & \\
\hline \multirow[t]{3}{*}{$\mathrm{pO}_{2}$} & \multirow[t]{3}{*}{ Rhesus monkey } & Follicular & $<10 \mathrm{mmHg}$ & 169 \\
\hline & & Follicular & $35 \mathrm{mmHg}$ & 170 \\
\hline & & Ovulation \& luteal & $57-61 \mathrm{mmHg}$ & \\
\hline
\end{tabular}

Fox, ${ }^{23}$ and Menezo and Guerin. ${ }^{24}$ Recently, Leese and coworkers ${ }^{25}$ provided an excellent review on the formation of oviductal fluid. It is not the intention of this article to review all the components reported in the oviductal fluid. Table 2 contains some of the reported compositions of oviductal fluid from humans and primates.

Similar to many other species, the oviductal fluid in the primate is rich in $\mathrm{K}^{+}$and $\mathrm{HCO}_{3}{ }^{-}$when compared with plasma. ${ }^{26-28}$ Estrogen appears to stimulate the production of oviductal fluid, as the greatest volume of oviductal fluid in human and monkeys was observed at midcycle, coincident with the estrogen peak. ${ }^{29,30}$ It has been suggested that estrogen may modulate the movement of ions across the oviductal epithelium and, thereby, influence the rate of fluid secretion. ${ }^{25}$ These data are consistent with an active regulation of oviductal function at the time of fertilization and early embryo development.

The nutrient requirement of the embryo changes as it grows. The importance of amino acids and nutrients to early preimplantation embryo development has been critically reviewed. ${ }^{31,32}$ Similar to many other animal species, human embryos consume pyruvate throughout the preimplantation period, and they use an increasing amount of glucose at compaction and blastocyst formation. ${ }^{33,34}$ In fact, a high level of glucose inhibits early embryonic development in a number of species including human. ${ }^{35}$ The concentrations of nutrients in the oviduct differ from those in plasma, and vary with the endocrine state. ${ }^{36}$ The concentration of glucose in human Fallopian tube fluid decreases sixfold between the follicular phase and midcycle. ${ }^{36}$ It was speculated that the decrease in glucose concentration of oviductal fluid from mated pig when compared to unmated pig $^{37}$ was a strategy of the oviduct to protect embryos from exposure to a high concentration of glucose. ${ }^{34}$ The importance of optimal 
nutrient concentrations is also reflected in experiments on sheep ${ }^{38}$ and mouse ${ }^{39}$ showing that embryo culture media based on nutrient concentrations in oviductal fluid are superior to conventional media in supporting embryo development in vitro. Similarly, the embryo has a differential requirement for amino acids at different stages of development, ${ }^{40}$ and media based on the amino acid content of oviductal fluid improve ovine blastocyst formation and hatching. ${ }^{41}$

Apart from simple organic and inorganic molecules, the oviduct synthesizes and releases a number of macromolecules. Interested readers are referred to reviews by Buhi and coworkers. ${ }^{42,43}$ Like many other animal species, the biosynthetic activity of the Fallopian tube increases at midcycle in the human. ${ }^{43}$ In pig and sheep, it has been further shown that biosynthetic activity is higher in the ampulla than it is in the isthmus. ${ }^{44,45}$ Some secretory proteins from the human Fallopian tube fluid, including oviduct-specific glycoprotein (OGP) ${ }_{1}^{46}$ corticosteroid-binding globulin-like protein ${ }^{47}$ and insulin-like growth factor-binding protein $3^{48}$ may be involved in fertilization and early embryonic development. Three high molecular weight embryotrophic glycoprotein fractions that stimulate mouse embryo development ${ }^{49}$ have recently been isolated from human-oviductal-cell-conditioned medium. ${ }^{50}$ The exact identities of these factors remain to be determined, but it is believed that these molecules are responsible for maternal-embryonic cross-talk during early preimplantation development. ${ }^{51}$

OGP is one of the major macromolecules secreted by the oviduct. The protein has been characterized in several species, including rhesus, ${ }^{52}$ baboon $^{53}$ and human. ${ }^{54}$ In human, OGP is localized to the secretory granules of oviductal cells in both the ampulla and isthmus regions. ${ }^{55}$ The human OGP gene ${ }^{54}$ and its promoter ${ }^{56}$ have been cloned and characterized. The presence of OGP around the time of ovulation suggests that it may play a role in fertilization and/or early embryonic development. ${ }^{46,57}$ In hamster, the molecule attaches to the ovulated oocyte and early embryo, ${ }^{46,58,59}$ and also associates with the blastomeres. ${ }^{60,61}$ Although the physiological role of OGP is unclear, the chitinase-like domains of OGP are believed to interact with the oligosaccharide moieties of the zona pellucida, thereby forming a protective shield around the oocyte and early embryo. ${ }^{58}$

\section{HORMONAL EFFECTS ON OVIDUCTAL EMBRYOS}

It is generally believed that progesterone is essential for inducing the changes in the oviduct and uterus necessary for embryo viability and implantation. Administration of an anti-progesterone antibody to mice at 32 hours postcoitum retarded embryonic development; most of the embryos remained at the 4-cell stage whereas the control embryos were at the 8-cell to morula stage at $54-58$ hours postcoitum. ${ }^{62}$ The antibody treatment also induced a change in wheatgerm-lectin binding sites in the oviductal ampulla at days 3 and 4 of pregnancy, ${ }^{63}$ but did not have noticeable effect on cultured mouse embryos. ${ }^{62}$

A similar conclusion was reached using the anti-progestin, RU486, in mice. ${ }^{64,65}$ 
However, the data on RU486 have to be interpreted with caution as this antiprogestin inhibits the development of mouse embryos in vitro. ${ }^{66,67}$ RU486 also affects oviductal embryo transport in this species. ${ }^{68}$ Using a dose that did not affect the development of cynomolgus monkey embryos in vitro, ${ }^{69}$ RU486 administration on day 2 after the presumed day of ovulation retarded preimplantation embryo growth in rhesus monkey. ${ }^{70}$ The retarded embryos had abnormal morphology ${ }^{71}$ and did not implant after transfer to naturally synchronized surrogate recipients. ${ }^{70}$

Apart from progesterone, estradiol may also affect embryo development indirectly via its effect on oviductal secretion. Two-cell mouse embryos cultured in oviductal fluid from estrogen-dominated donors were significantly less able to develop to morula or blastocyst and to implant than those cultured in either control medium or the progesterone-dominated oviductal fluid. ${ }^{72}$ No inhibitory effect was observed on embryo development when estradiol or progesterone was added directly to the control medium. Estradiol may exert its action by affecting growth factor signalling systems in the oviduct. It induces oviductal mRNA expression of IGF-I in $\mathrm{rat}^{73}$ and EGF, TGF- $\alpha$, and EGF receptor in human. ${ }^{17,74}$

\section{EFFECTS OF OVIDUCTAL CELLS ON EMBRYO DEVELOPMENT IN VITRO}

The above evidence demonstrates that the microenvironment in the oviductal fluid affects early preimplantation embryo development. However, the actual contribution of the oviductal cells on embryo development is uncertain, as the components in the oviductal fluid can be derived from plasma transudation and not solely from active secretion from the oviduct. It has been demonstrated that coculture of human embryos with human Fallopian tube cells improves the quality of the developing embryos. ${ }^{2,75,75-77}$ As these studies provide more direct evidence that oviductal cell activities do contribute to the embryotrophic effect of the oviduct, this aspect is discussed in greater detail below.

\section{COCULTURE STUDIES IN CLINICAL IVF}

There have been a number of clinical coculture trials using oviductal cells of human or bovine origin in assisted reproduction. Table 3 summarizes the results of these studies. Most of the studies are prospective randomized clinical trials. Apart from one study, coculture with oviductal cells improved embryo quality and/or enhanced pregnancy rate/implantation rate. For some unknown reason, Tucker and coworkers ${ }^{78}$ found no beneficial effect of oviductal cells for couples requiring intracytoplasmic sperm injection (ICSI). However, the indication for ICSI and whether couples were undergoing IVF for the first time were not mentioned. In addition to the clinical studies listed in Table 3, there are other in vitro experiments demonstrating that oviductal cells decreased embryo fragmentation, ${ }^{76}$ increased blastulation rate, ${ }^{76,79}$ the number of cells per blastocyst, ${ }^{79}$ and the hatching rate of human embryos. ${ }^{75}$ 
Table 3 Controlled clinical trials using oviductal cells

\begin{tabular}{|c|c|c|c|c|c|c|}
\hline $\begin{array}{l}\text { Somatic } \\
\text { cells origin }\end{array}$ & Patient & Study design & Coculture duration* & $\begin{array}{l}\text { Cocultured embryo } \\
\text { development }\end{array}$ & $\begin{array}{l}\text { Pregnancy/ } \\
\text { implantation\# }\end{array}$ & Reference \\
\hline \multirow[t]{5}{*}{ Bovine } & Non-male factors & Prospective randomized & 1 day after fertilization & $\begin{array}{l}\text { Less fragmentation } \\
\text { More blastomeres }\end{array}$ & Increase PR and IR & 171 \\
\hline & Non-male factors & Prospective randomized & 1 day after fertilization & $\begin{array}{l}\text { Less negative } \\
\text { morphological } \\
\text { characteristics }\end{array}$ & Increase PR & 172 \\
\hline & $\begin{array}{l}\text { Female } \geq 38 \text { years; } \\
\text { multiple failed IVF } \\
\text { attempts }\end{array}$ & $\begin{array}{l}\text { Prospective randomized; } \\
\text { + assisted hatching }\end{array}$ & 2 days after fertilization & $\begin{array}{l}\text { More zona thickness } \\
\text { variability }\end{array}$ & Increase PR & 80 \\
\hline & $\begin{array}{l}\text { Multiple failed IVF } \\
\text { attempts; non-male } \\
\text { factor }\end{array}$ & $\begin{array}{l}\text { Previous IVF as control; } \\
\quad \text { + assisted hatching }\end{array}$ & 2 days after fertilization & $\begin{array}{l}\text { More blastomeres } \\
\text { Les fragmentation }\end{array}$ & Not compared & 81 \\
\hline & ICSI patients & Prospective randomized & 3 days after ICSI & No difference & No difference & 78 \\
\hline
\end{tabular}

ICSI, intracytoplasmic sperm injection; IR, implantation rate; IVF, in vitro fertilization; PR, pregnancy rate.

* Duration after fertilization check

\#When compared with control

** When compared with patients performing conventional IVF in the same period 
It has been suggested that oviductal cell coculture is suitable for poor prognosis patients, such as patients of advanced age, ${ }^{80}$ patients with multiple failed IVF attempts, ${ }^{80,81}$ and patients with a high basal level of follicle stimulating hormone. ${ }^{82}$ Coculture may not be required for young ( $<35$ years) first-time IVF patients as there is no difference in pregnancy rates in these patients with or without coculture, though the development of the embryos is improved after coculture. ${ }^{83}$ This group of patients with a good prognosis is likely to produce sufficiently good quality embryos that are competent to development in vitro.

\section{LIMITATIONS OF COCULTURE STUDIES}

Although oviductal cell coculture intends to imitate the in vivo condition, this objective cannot be achieved with the current model because the culture requirements of the somatic cells and the embryos are different. In a coculture system, only one culture medium, commonly the embryo culture medium, is used. Thus, the somatic cells are grown under suboptimal conditions. Walter ${ }^{84}$ concluded that monolayers of bovine oviduct epithelial cells could not fully substitute for the oviduct epithelium when used in coculture experiments. Thus, cultured somatic cells may not function optimally in a coculture system.

To improve the efficiency of coculture, optimization of coculture conditions is important. In our experience the best coculture system using human oviductal cells with Earles' balanced salt solution is when the cells are at the rapidly growing phase. We usually seed $5 \times 10^{4}$ cells in a 4 -well plate and the cells will be ready to use the next day. Wiemer and coworkers ${ }^{83}$ reported similar observations with bovine oviductal epithelial cells. They suggested that confluent cells and actively dividing nonconfluent monolayers might secrete different levels of embryotrophic factors, and that steroid treatment affected the plating efficiency of bovine oviductal cells. ${ }^{83}$ Confluent oviductal cell culture will cause the detachment and death of epithelial cells, leading to an increase in the acidity of the medium which is deleterious to embryo development.

During coculture, the observed effects on embryo development are the consequence of two opposing activities; namely, the embryotrophic effect of somatic cells and the combined deleterious effect of excretory waste from the somatic cells, proteases released by the somatic cells as a result of cell death and inappropriate competition of nutrients between the somatic cells and the embryos. This was shown in one of our unpublished experiments (Liu LPS and Yeung WSB) in which mouse embryos were cultured in spent media after culturing the oviductal cells for different durations and in media containing only the high molecular weight embryotrophic fraction of the conditioned media. Figure 1 shows the results of the experiment. Conditioned medium had its maximal embryotrophic effect after 6-9 hours of conditioning, but became inhibitory after 24 hours. On the other hand, the embryotrophic effect of the high molecular weight factors accumulated with time, reaching a plateau after 6 hours of conditioning. It has been reported that cocultured embryos are 


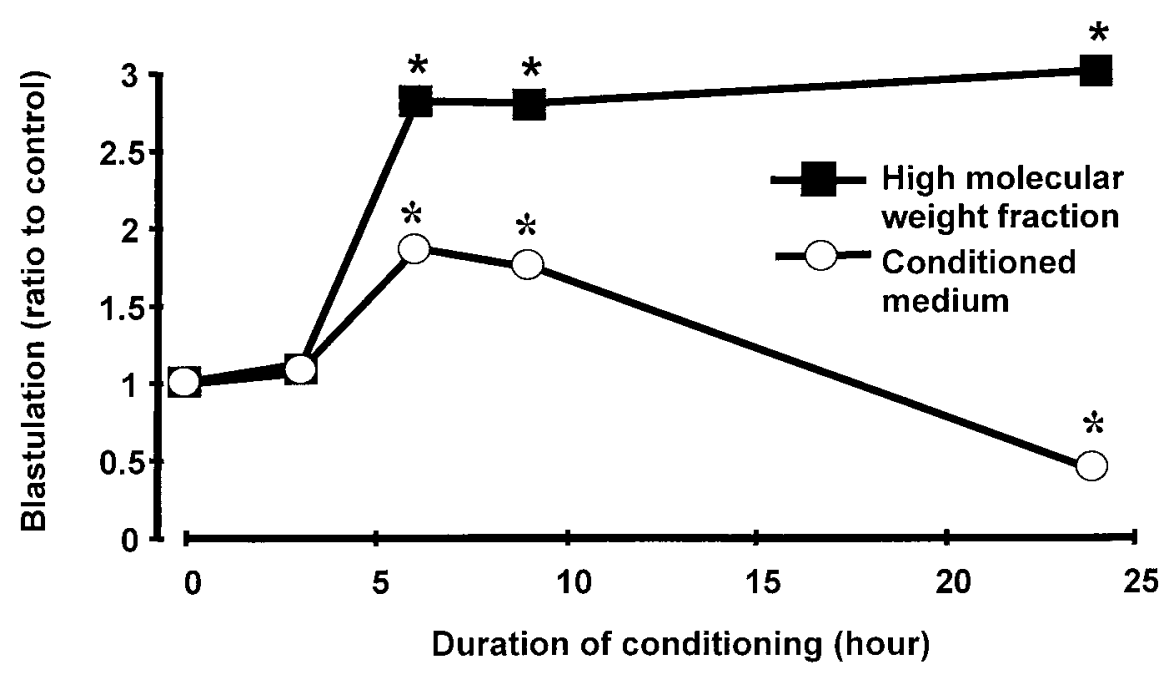

Figure 1 Effect of duration of conditioning of the embryotrophic activity of human oviductal cells on mouse embryo development. The percentage of blastulation in medium-alone culture was arbitrary taken as unity. Results of various treatments were expressed as ratios to the control. ${ }^{*} P<0.05$ when compared with the control (ANOVA)

subjected to dynamic changes of growth factors/cytokines released by Vero cells ${ }^{85}$ and that the culture condition will affect the secretion of growth factors by the cells. ${ }^{86}$

The results of a number of reports on the use of somatic cells other than oviductal cells for coculture with human embryos are much more variable. Assisted reproduction without the involvement of the Fallopian tube can give rise to live birth, indicating that the coculture embryotrophic effect is facilitatory and not obligatory to embryo development. In many coculture studies, the embryos were cocultured for only 1-2 days. This short coculture period may not be sufficient to induce an effect that can be manifested as an increase in pregnancy rate. The embryotrophic effect is further diminished when the number of somatic cells available, e.g. granulosa cells, is limited. Therefore, it is likely to be more difficult to demonstrate an increase in pregnancy rates in these studies. ${ }^{87}$

Despite the general observation of enhanced embryo development after oviductal cell coculture, it is not used in most human assisted reproduction programmes because of the complexity of its implementation as a routine service and the limitations listed above. In addition, there is risk of transfer of disease from contaminated cultures to the embryos during coculture. ${ }^{88} \mathrm{~A}$ safer and more practical approach is to produce a chemically defined embryo culture system. ${ }^{89}$ Consequently, the recent development of the sequential culture, the use of different culture media for culturing embryos at different stages of development, has rapidly become the method of choice for improving the outcome in human assisted reproduction programmes. $^{3}$ 
Coculture and sequential culture are not mutually exclusive, and in fact they can complement each another. The human Fallopian tube produces granulocyte-macrophage colony-stimulating factor (GM-CSF) with a peak expression in the preimplantation period. ${ }^{90}$ GM-CSF has recently been shown to improve human embryo development in the G1.2/G2.2 sequential culture medium system. ${ }^{91}$ Its receptor mRNA is present in mouse embryos at all stages of development. ${ }^{92}$ These data suggest that the present sequential culture system is not yet optimal, and that we can further improve the system by studying the mechanisms by which oviductal cells improve embryo development. Indeed, new sequential media may obviate the need for coculture.

\section{OVIDUCTAL EMBRYOTROPHIC MECHANISMS}

The exact mechanisms of oviductal embryotrophic activity in vivo are unclear. Most of the information in this area is based on in vitro coculture studies. However, the use of coculture to study oviductal embryotrophic mechanisms in human embryo development is difficult because the availability of human embryos for research is limited for ethical reasons. Very often mouse embryos are used instead.

Characterization of oviductal embryotrophic mechanisms using coculture faces two problems. The first is that oviductal cells produce minute amount of embryotrophic factors making characterization of these factors difficult. The problem is aggravated as human oviductal cells have a limited proliferative life span in culture, posing more difficulty in isolating sufficient embryotrophic factors. We have recently established an immortalized human oviductal cell line ${ }^{93}$ that retains most of the characteristics of primary oviductal cells including the production of OGP and some embryotrophic factors. In future, this cell line will be a valuable tool for studying the interaction between oviductal cells and embryos.

The second problem arises because the actions of oviductal embryotrophic factors are only facilitatory to embryonic development. In coculture experiments using mouse embryos, the ability to detect embryotrophic activity is often low because the development of many mouse strains does not require additional support in standard culture conditions for blastulation, the usual endpoint in these studies. In order to increase the sensitivity of detection, we use a mouse strain with low developmental potential in commonly used mouse culture media to assess the coculture embryotrophic effect. With this model, we detect the presence of three embryotrophic factors, termed ETF-1, -2, -3, in spent medium after human oviductal cell culture. ${ }^{49,50}$

There are three proposed mechanisms of embryotrophic activity in coculture; namely, positive conditioning, negative conditioning and cell-to-embryo contact. Positive conditioning refers to the production of embryotrophic factors by the somatic cells. During preimplantation embryo development, numerous peptide growth factors, their corresponding receptors and binding proteins are expressed in the oviduct of human, mouse and other domestic animals (Table 1). The expression of many of these growth factors, e.g. IGF-1, ${ }^{19,94}$ IGF-2, ${ }^{19}$ TGF- $\alpha$, EGF $^{14,17}$ (full names of 
IGF, TGF $\alpha$ and EGF can be found on p. 22), is highest from mid-cycle to the early luteal phase, a time when the preimplantation embryo is in the oviduct. Many of the corresponding growth factor receptors are also expressed in the embryos within this period. Paracrine interaction between the oviduct and human preimplantation embryos via growth factors is indicated by the observation that addition of growth factors, e.g. IGF- $1^{21}$, leukaemia inhibitory factor $(\mathrm{LIF})^{95}$ or heparin binding-epidermal growth factor, ${ }^{96}$ to the culture medium facilitates human embryo development in vitro. Apart from growth factors, OGP binds to the zona pellucida and blastomeres of hamster embryo, ${ }^{61}$ suggesting a possible role of this molecule in early embryo development. Hunter ${ }^{97}$ proposed that oviduct glycoproteins might increase the viscosity of luminal fluid, thereby preventing the dispersal of essential nutrients and ions and stabilizing the microenvironment immediately surrounding the embryos. However, this is difficult to test in vivo as the oviduct plays only a facilitatory role in embryo development.

It is unknown how the embryotrophic factors affect embryo development. When compared to embryos cultured in medium alone, human oviductal cell coculture affects the gene expression profiles of mouse embryos, ${ }^{98}$ and reduces the incidence of apoptosis at the morula and blastocyst stage. ${ }^{99}$ Human $^{19,21,94}$ and bovine ${ }^{100}$ oviductal cells express IGF-1. Exogenous IGF-I improved human embryo development partly by decreasing the incidence of blastomere apoptosis in the treated embryos, ${ }^{101}$ leading to an increase in the number of cells within the inner cell mass. ${ }^{21}$

Our recent data show that human oviductal cells produce three embryotrophic factors, ETF-1, -2 and -3 in vitro. ${ }^{50}$ These factors are unlikely to be common growth factors as they have much larger molecular sizes. The stimulatory activity of ETF-3 on mouse blastulation is unaffected by antibodies against TGF- $\alpha$, TGF- $\beta$, IGF-II, IGFBP3 (Xu and Yeung, unpublished observations). These factors have differential spatial and temporal effects on the development of mouse embryos. ${ }^{102}$ Thus, ETF-1 and ETF-2 treatment covering the period of 48-72 hours after human chorionic gonadotrophin injection (hCG) increased cell numbers in the inner cell mass of the resulting blastocyst, whilst ETF-3 treatment covering 96-120 hours post-hCG increased the cell number in the trophectoderm. The improved development of trophectoderm after ETF-3 treatment resulted in larger blastocysts that hatched, attached to and spread on culture dishes more often than was seen in untreated controls. These results suggest that the response of embryos to embryotrophic factors changes as the embryos develop. We are currently investigating whether the response of the embryos to ETF-3 treatment is affected by prior treatment with ETF- 1 and -2. In this connection, human endometrial stromal cells enhance the expression of IGF receptors in cocultured human embryos, ${ }^{103}$ which might then become more sensitive to subsequent IGF treatment.

It is believed that conventional embryo culture conditions are not optimal. Negative conditioning refers to the removal of the suboptimal culture condition by coculture with somatic cells, leading to improved embryo development. The level of superoxide anion in culture medium is significantly reduced by human oviductal cell coculture. ${ }^{104}$ Bovine oviductal cells improve embryo development partly by altering 
the carbohydrate concentrations in the culture medium. ${ }^{105}$ However, this embryotrophic mechanism is likely to be an artefact in vitro and may not represent the situation in vivo. Somatic cell-to-embryo contact has been shown to be unimportant in human oviductal cells coculture. ${ }^{106}$ However, contradictory observations have also been reported. ${ }^{104}$

Although various cell types exert embryotrophic activity on embryonic development in vitro, they may act via distinct mechanisms. Different cell types secrete different growth factors. Human oviductal cells express EGF, LIF, colony stimulating factor-1 and interleukin-6 (IL-6) while buffalo rat liver cells do not express LIF and IL-6. ${ }^{107}$ Vero cells, but not human oviductal cells, improve mouse embryo development partly by altering the concentration of nutrients in the culture medium. ${ }^{108}$ Therefore, it is surprising that the efficacy of coculture is different among the somatic cells used. In cattle, oviductal epithelial cell coculture produces better embryos than does coculture with granulosa cells, ${ }^{109}$ oviductal stromal cells or endometrial epithelial cells. ${ }^{110}$ The post-transfer development of bovine embryos is also better for embryos after coculture with oviductal cells than it is with those after coculture with bovine fetal uterine fibroblasts. ${ }^{83}$ Although both sheep oviductal cells and fibroblast coculture stimulate embryo development in vitro, the development of sheep embryos after transfer following oviductal coculture is superior to that of embryos after fibroblast coculture. ${ }^{1}$ Similarly, we also found that human oviductal epithelial cells were better than oviductal fibroblast in enhancing mouse blastulation. ${ }^{49}$ In a prospectively randomized study, coculture with human fibroblasts did not improve embryo quality and pregnancy rate when compared to conventional medium alone. ${ }^{111}$

\section{EFFECTS OF EMBRYO ON OVIDUCTAL ACTIVITY}

Most of the coculture studies investigate the effect of oviductal cells on embryo development. There are some reports demonstrating that the embryos also affect oviductal physiology in animals. Although similar reports of humans are lacking, the machinery for such interaction has been demonstrated in human oviduct and embryos, suggesting that similar activity may also be present.

In mice, the vasculature of the oviduct containing 2-cell embryos is different to that in pseudopregnant mice without embryos. ${ }^{12}$ Platelet activating factor (PAF) may be involved in these vascular changes. ${ }^{112}$ PAF is produced by early embryos from a number of species including mouse, ${ }^{113,114}$ sheep $^{115}$ and human. ${ }^{116}$ It alters several aspects of the maternal physiology during early pregnancy including systemic platelet count (inducing thrombocytopenia ${ }^{116}$ ) and endometrial prostaglandin secretion. ${ }^{117}$ The presence of the PAF receptor has recently been reported in human Fallopian tube ${ }^{118}$ and bovine oviduct. ${ }^{119}$ PAF increases the potential difference and short-circuit current when applied to the apical surface of human oviduct ${ }^{120}$ and increases the intracellular free calcium concentration ${ }^{121}$ and proliferation ${ }^{122}$ in bovine oviductal cells in culture.

Fertilized embryos are transported down the oviduct at a faster rate than 
unfertilized ova in hamsters, ${ }^{123}$ rat, ${ }^{124}$ bats ${ }^{125}$ and mares. ${ }^{126}$ Evidence suggests that the development of embryos influences the timing of their entrance to the uterus in the rat. ${ }^{124}$ Equine embryos secrete prostaglandin $E_{2}$ immediately before and during the expected time of transport from oviduct to the uterus. ${ }^{127}$ Prostaglandin $\mathrm{E}_{2}$ has been shown to hasten this transport in the mare. ${ }^{128}$ In hamsters, PAF stimulates oviductal transport of embryos, ${ }_{1}^{129}$ probably by stimulating the frequency of the ciliary beat in oviductal cells. ${ }^{130,131}$ Similar data are not available for humans.

TGF $\beta$ - 1 mRNA expression in mice is high in the 8-cell embryo and morula, but drops significantly at the blastocyst stage. ${ }^{132}$ However, the functional receptor for this growth factor can only be detected in the blastocyst. This suggests that the production of TGF $\beta-1$ by the early embryo before compaction may be relevant to its paracrine action on the oviduct. This is supported by our detection of TGF $\beta-1$ receptor expression in the oviduct throughout preimplantation embryo development. There are also indications that intra-oviductal embryos can exert a biological effect on the uterus, enhancing endometrial receptivity. ${ }^{133}$ It is unlikely that an oviductal embryo with a few blastomeres is able to produce sufficient quantities of active components to affect the physiology of other organs. In fact, embryo-derived PAF has a systemic effect on thrombocytopenia in early pregnancy. ${ }^{134}$ It is more likely that embryoderived factors affect the nearby oviductal cells, which amplify the embryonic signal and modify the physiology of the maternal system. Embryos have been shown to stimulate the production of IGFBP-3 by human oviductal cells. ${ }^{48} \mathrm{~A}$ similar conclusion was reached in a mouse embryo/human endometrial cell coculture system. ${ }^{135}$

\section{CONCLUSION}

The reproductive tract creates a dynamic environment for the optimal development of mammalian embryos in vivo. In nature, all embryos are exposed to the oviductal microenvironment after fertilization. Data suggest that the oviductal environment is important for the development of embryos and that there is complex cross-talk between embryos and the oviduct. The best available medium today contains only a small subset of the components present in the oviductal environment. Although the embryo can adapt to its environment, ${ }^{34,136}$ the inadequacy of the medium inevitably causes stress to the cultured embryos. ${ }^{137}$ This may be one reason for the low success rate in clinical assisted reproduction. To improve this situation, improved knowledge of the oviductal microenvironment is crucial. Unfortunately, information on this aspect is rather limited.

Coculture is a good model, though with some pitfalls, for giving clues to the possible mechanisms of interaction between the embryo and the oviduct. Its utilization in clinical assisted reproduction has generated some controversy. ${ }^{138,139}$ The arguments against its use include the fact that coculture is not chemically defined, making interpretation difficult, and coculture embryotrophic effects may only represent a remedy for artefacts created by conventional suboptimal culture conditions. ${ }^{89,140}$ The pursuit of specific oviduct factors in coculture and the confirma- 
tion of the embryotrophic activity by adding these factors to chemically defined medium would help to solve the controversy. Future work should focus on the normal physiology and biochemistry of the oviduct and the early embryo.

A word of caution for the supplementation of only some embryotrophic factors to the embryo culture medium is necessary. Some embryotrophic factors have specific effects on certain cell types of embryos. For instance, ETF-3 affects mainly trophectoderm cells. The effect of a selective increase in the development of trophectoderm on subsequent fetal development remains to be determined. In this context, it has been reported that larger calves are born after coculture with tubal cells, ${ }^{141,142}$ and that the percentage of male calves is increased after coculture with bovine oviduct epithelial cells and Vero cells. ${ }^{143}$ Rigorous controlled studies will be necessary before suggesting the application of media supplemented with embryotrophic factors to clinical assisted reproduction.

\section{Acknowledgement}

This work was supported fully by grants (HKU39/91, HKU241/95M and HKU 7333/ 97M) to WSBY from the Research Grant Council, Hong Kong.

\section{REFERENCES}

1 Gandolfi F, Moor RM. Stimulation of early embryonic development in the sheep by co-culture with oviduct epithelial cells. J Reprod Fertil 1987; 81: 23-8.

2 Bongso A, Ng SC, Fong CY, Anandakumar C, Marshall B, Edirisinghe R, Ratnam S. Improved pregnancy rate after transfer of embryos grown in human fallopian tubal cell coculture. Fertil Steril 1992; 58: 569-74.

3 Gardner DK, Schoolcraft WB, Wagley L, Schlenker T, Stevens J, Hesla J. A prospective randomized trial of blastocyst culture and transfer in in-vitro fertilization. Hum Reprod 1998; 13: $3434-40$.

4 Suarez SS. Carbohydrate-mediated formation of the oviductal sperm reservoir in mammals. Cells Tissues Organs 2001; 168: 105-12.

5 Suarez SS. The oviductal sperm reservoir in mammals: mechanisms of formation. Biol Reprod 1998; 58: 1105-7.

6 Baillie HS, Pacey AA, Warren MA, Scudamore IW, Barratt CL. Greater numbers of human spermatozoa associate with endosalpingeal cells derived from the isthmus compared with those from the ampulla. Hum Reprod 1997; 12: 1985-92.

7 Yao Y, Ho P, Yeung WS. Human oviductal cells produce a factor(s) that maintains the motility of human spermatozoa in vitro. Fertil Steril 2000; 73: 479-86.

8 Yao YQ, Ho PC, Yeung WS. Effects of human oviductal cell coculture on various functional parameters of human spermatozoa. Fertil Steril 1999; 71: 232-9.

9 Yeung WS, Ng VK, Lau EY, Ho PC. Human oviductal cells and their conditioned medium maintain the motility and hyperactivation of human spermatozoa in vitro. Hum Reprod 1994; 9: 656-60.

10 Brenner RM, Slayden OD. Cyclic changes in the primate oviduct and endometrium. In: The Physiology of Reproduction, 2nd edn. New York: Raven Press, 1994, p. 541. 
11 Comer MT, Leese HJ, Southgate J. Induction of a differentiated ciliated cell phenotype in primary cultures of Fallopian tube epithelium. Hum Reprod 1998; 13: 3114-20.

12 Kane MT, Morgan PM, Coonan C. Peptide growth factors and preimplantation development. Hum Reprod Update 1997; 3: 137-57.

13 Kaye PL, Harvey MB. The role of growth factors in preimplantation development. Prog Growth Factor Res 1995; 6: 1-24.

14 Kurachi H, Morishige K, Imai T, Homma H, Masumoto N, Yoshimoto Y, Miyake A. Expression of epidermal growth factor and transforming growth factor-alpha in fallopian tube epithelium and their role in embryogenesis. Horm Res 1994; 41 [Suppl 1]: 48-54.

15 Morishige K, Kurachi H, Amemiya K, Adachi H, Adachi K, Sakoyama Y, Miyake A, Tanizawa O. Menstrual stage-specific expression of epidermal growth factor and transforming growth factor-alpha in human oviduct epithelium and their role in early embryogenesis. Endocrinology 1993; 133: 199-207.

16 Smotrich DB, Stillman RJ, Widra EA, Gindoff PR, Kaplan P, Graubert M, Johnson KE. Immunocytochemical localization of growth factors and their receptors in human pre-embryos and Fallopian tubes. Hum Reprod 1996; 11: 184-90.

17 Adachi K, Kurachi H, Adachi H, Imai T, Sakata M, Homma H, Higashiguchi O, Yamamoto T, Miyake A. Menstrual cycle specific expression of epidermal growth factor receptors in human fallopian tube epithelium. J Endocrinol 1995; 147: 553-63.

18 Hemmings R, Langlais J, Falcone T, Granger L, Miron P, Guyda H. Human embryos produce transforming growth factor alpha activity and insulin-like growth factor II. Fertil Steril 1992; 58: $101-4$.

19 Jin HY, Wang ZN. Insulin-like growth factors and their receptors in human fallopian tube in reproductive-age women. Fertil Steril 2001; 75: 1037-8.

20 Lighten AD, Hardy K, Winston RM, Moore GE. Expression of mRNA for the insulin-like growth factors and their receptors in human preimplantation embryos. Mol Reprod Dev 1997; 47: 134-9.

21 Lighten AD, Moore GE, Winston RM, Hardy K. Routine addition of human insulin-like growth factor-I ligand could benefit clinical in-vitro fertilization culture. Hum Reprod 1998; 13: 3144-50.

22 Leese HJ. The formation and function of oviduct fluid. J Reprod Fertil 1988; 82: 843-56.

23 Hamner CE, Fox SB. Biochemistry of oviductal secretions. In: The Mammalian Oviduct: Comparative Biology and Methodology. Chicago, IL: University of Chicago Press, 1969, pp 333-56.

24 Menezo Y, Guerin P. The mammalian oviduct: biochemistry and physiology. Eur I Obstet Gynecol Reprod Biol 1997; 73: 99-104.

25 Leese HJ, Tay JI, Reischl J, Downing SJ. Formation of Fallopian tubal fluid: role of a neglected epithelium. Reproduction 2001; 121:339-46.

26 Lippes I, Enders RG, Pragay DA, Bartholomew WR. The collection and analysis of human fallopian tubal fluid. Contraception 1972; 5: 85-103.

27 David A, Serr DM, Czernobilsky B. Chemical composition of human oviduct fluid. Fertil Steril 1973; 24: 435-9.

28 Maas DH, Storey BT, Mastroianni L Jr. Hydrogen ion and carbon dioxide content of the oviductal fluid of the rhesus monkey (Macaca mulatta). Fertil Steril 1977; 28: 981-5.

29 Lippes J, Krasner J, Alfonso LA, Dacalos ED, Lucero R. Human oviductal fluid proteins. Fertil Steril 1981; 36: 623-9.

30 Perkins JL. Fluid flow of the oviduct. In: The Oviduct and its Functions. New York: Academic Press, 1974, pp. 119-32.

31 Gardner DK. Changes in requirements and utilization of nutrients during mammalian preimplantation embryo development and their significance in embryo culture. Theriogenology 1998; 49: 83-102. 
32 Gardner DK, Pool TB, Lane M. Embryo nutrition and energy metabolism and its relationship to embryo growth, differentiation, and viability. Semin Reprod Med 2000; 18: 205-18.

33 Leese HI, Conaghan J, Martin KL, Hardy K. Early human embryo metabolism. Bioessays 1993; 15: $259-64$.

34 Leese HJ. Metabolic control during preimplantation mammalian development. Hum Reprod Update 1995; 1: 63-72.

35 Conaghan J, Handyside AH, Winston RM, Leese HJ. Effects of pyruvate and glucose on the development of human preimplantation embryos in vitro. J Reprod Fertil 1993; 99: 87-95.

36 Gardner DK, Lane M, Calderon I, Leeton J. Environment of the preimplantation human embryo in vivo: metabolite analysis of oviduct and uterine fluids and metabolism of cumulus cells. Fertil Steril 1996; 65: 349-53.

37 Nichol R, Hunter RH, Gardner DK, Leese HI, Cooke GM. Concentrations of energy substrates in oviductal fluid and blood plasma of pigs during the peri-ovulatory period. I Reprod Fertil 1992; 96: 699-707.

38 Tervit HR, Whittingham DG, Rowson LE. Successful culture in vitro of sheep and cattle ova. I Reprod Fertil 1972; 30: 493-7.

39 Gardner DK, Leese HJ. Concentrations of nutrients in mouse oviduct fluid and their effects on embryo development and metabolism in vitro. J Reprod Fertil 1990; 88: 361-8.

40 Steeves TE, Gardner DK. Temporal and differential effects of amino acids on bovine embryo development in culture. Biol Reprod 1999; 61: 731-40.

41 Walker SK, Hill JL, Kleemann DO, Nancarrow CD. Development of ovine embryos in synthetic oviductal fluid containing amino acids at oviductal fluid concentrations. Biol Reprod 1996; 55: 703-8.

42 Buhi WC, Alvarez IM, Kouba AJ. Oviductal regulation of fertilization and early embryonic development. J Reprod Fertil Suppl 1997; 52: 285-300.

43 Buhi WC, Alvarez IM, Kouba AJ. Secreted proteins of the oviduct. Cells Tissues Organs 2000; 166: 165-79.

44 Buhi WC, Bazer FW, Alvarez IM, Mirando MA. In vitro synthesis of oviductal proteins associated with estrus and 17 beta-estradiol-treated ovariectomized ewes. Endocrinology 1991; 128: 3086-95.

45 Buhi WC, Ashworth CJ, Bazer FW, Alvarez IM. In vitro synthesis of oviductal secretory proteins by estrogen-treated ovariectomized gilts. J Exp Zool 1992; 262: 426-35.

46 O'DayBowman MB, Mavrogianis PA, Reuter LM, Johnson DE, Fazleabas AT, Verhage HG. Association of oviduct-specific glycoproteins with human and baboon (Papio anubis) ovarian oocytes and enhancement of human sperm binding to human hemizonae following in vitro incubation. Biol Reprod 1996; 54: 60-9.

47 Baltes P, Sanchez R, Pena P, Villegas J, Turley H, Miska W. Evidence for the synthesis and secretion of a CBG-like serpin by human cumulus oophorus and fallopian tubes. Andrologia 1998; 30: 249-53.

48 Lai YM, Wang HS, Lee CL, Lee JD, Huang HY, Chang FH, Lee JF, Soong YK. Insulin-like growth factor-binding proteins produced by Vero cells, human oviductal cells and human endometrial cells, and the role of insulin-like growth factor-binding protein-3 in mouse embryo co-culture systems. Hum Reprod 1996; 11: 1281-6.

49 Liu LP, Chan ST, Ho PC, Yeung WS. Human oviductal cells produce high molecular weight factor(s) that improves the development of mouse embryo. Hum Reprod 1995; 10: 2781-6.

50 Liu LP, Chan ST, Ho PC, Yeung WS. Partial purification of embryotrophic factors from human oviductal cells. Hum Reprod 1998; 13: 1613-19.

51 Hill JA. Maternalembryonic cross-talk. Ann N Y Acad Sci 2001; 943: 17-25.

52 Verhage HG, Mavrogianis PA, Boomsma RA, Schmidt A, Brenner RM, Slayden OV, Jaffe RC. Immunologic and molecular characterization of an estrogen-dependent glycoprotein in the rhesus (Macaca mulatta) oviduct. Biol Reprod 1997; 57: 525-31. 
53 Donnelly KM, Fazleabas AT, Verhage HG, Mavrogianis PA, Jaffe RC. Cloning of a recombinant complementary DNA to a baboon (Papio anubis) estradiol-dependent oviduct-specific glycoprotein. Mol Endocrinol 1991; 5: 356-64.

54 Arias EB, Verhage HG, Jaffe RC. Complementary deoxyribonucleic acid cloning and molecular characterization of an estrogen-dependent human oviductal glycoprotein. Biol Reprod 1994; 51: 685-94.

55 O'Day-Bowman MB, Mavrogianis PA, Fazleabas AT, Verhage HG. A human oviduct-specific glycoprotein: synthesis, secretion, and localization during the menstrual cycle. Microsc Res Tech 1995; 32: 57-69.

56 Agarwal A, Yeung WS, Lee KF. Cloning and characterisation of the Human Oviduct-specific Glycoprotein (HuOGP) Promoter. Mol Hum Reprod 2002; 8: 167-75.

57 Verhage HG, Mavrogianis PA, O’Day-Bowman MB, Schmidt A, Arias EB, Donnelly KM, Boomsma RA, Thibodeaux JK, Fazleabas AT, Jaffe RC. Characteristics of an oviductal glycoprotein and its potential role in the fertilization process. Biol Reprod 1998; 58: 1098-101.

58 Malette B, Paquette Y, Merlen Y, Bleau G. Oviductins possess chitinase- and mucin-like domains: a lead in the search for the biological function of these oviduct-specific ZP- associating glycoproteins. Mol Reprod Dev 1995; 41: 384-97.

59 Kan FW, St Jacques S, Bleau G. Immunocytochemical evidence for the transfer of an oviductal antigen to the zona pellucida of hamster ova after ovulation. Biol Reprod 1989; 40: 585-98.

60 Kan FW, Roux E. Elaboration of an oviductin by the oviductal epithelium in relation- to embryo development as visualized by immunocytochemistry. Microsc Res Tech 1995; 31: 47887.

61 Murray M, Messinger SM. Early embryonic development in the Diungarian hamster (Phodopus sungorus) is accompanied by alterations in the distribution and intensity of an estrogen (E2)dependent oviduct glycoprotein in the blastomere membrane and zona pellucida and in its association with F-actin. Biol Reprod 1994; 51: 1126-39.

62 Rider V, Heap RB, Wang MY, Feinstein A. Anti-progesterone monoclonal antibody affects early cleavage and implantation in the mouse by mechanisms that are influenced by genotype. $J$ Reprod Fertil 1987; 79: 33-43.

63 Whyte A, Yang C, Rutter F, Heap RB. Lectin-binding characteristics of mouse oviduct and uterus associated with pregnancy block by autologous antiprogesterone monoclonal antibody. $J$ Reprod Immunol 1987; 11: 209-19.

64 Roblero LS, Fernandez O, Croxatto HB. The effect of RU486 on transport, development and implantation of mouse embryos. Contraception 1987; 36: 549-55.

65 McRae AC. Effects of the anti-progestin and anti-glucocorticoid steroid RU486 on cell proliferation in oviductal embryos of lactating mice. I Reprod Fertil 1994; 100: 307-13.

66 Juneja SC, Dodson MG. Effect of RU486 on different stages of mouse preimplantation embryos in vitro. Can J Physiol Pharmacol 1990; 68: 1457-60.

67 Yang YQ, Wu JT. RU 486 interferes with egg transport and retards the in vivo and in vitro development of mouse embryos. Contraception 1990; 41: 551-6.

68 Vinijsanun A, Martin L. Effects of progesterone antagonists RU486 and ZK98734 on embryo transport, development and implantation in laboratory mice. Reprod Fertil Dev 1990; 2: 713-27.

69 Wolf JP, Chillik CF, Dubois C, Ulmann A, Baulieu EE, Hodgen GD. Tolerance of perinidatory primate embryos to RU 486 exposure in vitro and in vivo. Contraception 1990; 41: 85-92.

70 Ghosh D, Kumar PG, Sengupta J. Early luteal phase administration of mifepristone inhibits preimplantation embryo development and viability in the rhesus monkey. Hum Reprod 1997; 12: $575-82$.

71 Ghosh D, Lalitkumar PG, Wong VJ, Hendrickx AG, Sengupta J. Preimplantation embryo morphology following early luteal phase anti-nidatory treatment with mifepristone (RU486) in the rhesus monkey. Hum Reprod 2000; 15: 180-8.

72 Cline EM, Randall PA, Oliphant G. Hormone-mediated oviductal influence on mouse embryo development. Fertil Steril 1977; 28: 766-71.

73 Carlsson B, Hillensjo T, Nilsson A, Tornell J, Billig H. Expression of insulin-like growth factor-I 
(IGF-I) in the rat fallopian tube: possible autocrine and paracrine action of fallopian tube-derived IGF-I on the fallopian tube and on the preimplantation embryo. Endocrinology 1993; 133: 203-19.

74 Adachi K, Kurachi H, Homma H, Adachi H, Imai T, Sakata M, Higashiguchi O, Yamaguchi M, Morishige K, Sakoyama Y. Estrogen induces epidermal growth factor (EGF) receptor and its ligands in human fallopian tube: involvement of EGF but not transforming growth factor-alpha in estrogen-induced tubal cell growth in vitro. Endocrinology 1995; 136: 2110-19.

75 Yeung WS, Ho PC, Lau EY, Chan ST. Improved development of human embryos in vitro by a human oviductal cell co-culture system. Hum Reprod 1992; 7: 1144-9.

76 Bongso A, Soon-Chye N, Sathananthan H, Lian NP, Rauff M, Ratnam S. Improved quality of human embryos when co-cultured with human ampullary cells. Hum Reprod 1989; 4: 706-13.

77 Yeung WS, Lau EY, Chan ST, Ho PC. Coculture with homologous oviductal cells improved the implantation of human embryos a prospective randomized control trial. I Assist Reprod Genet 1996; 13: 762-7.

78 Tucker MJ, Morton PC, Wright G, Ingargiola PE, Sweitzer CL, Elsner CW, Mitchell-Leef DE, Massey JB. Enhancement of outcome from intracytoplasmic sperm injection: does co-culture or assisted hatching improve implantation rates? Hum Reprod 1996; 11: 2434-7.

79 Vlad M, Walker D, Kennedy RC. Nuclei number in human embryos co-cultured with human ampullary cells. Hum Reprod 1996; 11: 1678-86.

80 Tucker MJ, Ingargiola PE, Massey JB, Morton PC, Wiemer KE, Wiker SR, Wright G. Assisted hatching with or without bovine oviductal epithelial cell co-culture for poor prognosis in-vitro fertilization patients. Hum Reprod 1994; 9: 1528-31.

81 Wiemer KE, Garrisi J, Steuerwald N, Alikani M, Reing AM, Ferrara TA, Noyes N, Cohen J. Beneficial aspects of co-culture with assisted hatching when applied to multiple-failure in-vitro fertilization patients. Hum Reprod 1996; 11: 2429-33.

82 Wiemer KE, Hu Y, Cuervo M, Genetis P, Leibowitz D. The combination of coculture and selective assisted hatching: results from their clinical application. Fertil Steril 1994; 61: 105-10.

83 Wiemer KE, Cohen J, Tucker MJ, Godke RA. The application of co-culture in assisted reproduction: 10 years of experience with human embryos. Hum Reprod 1998; 13 [Suppl 4]: 22638.

84 Walter I. Culture of bovine oviduct epithelial cells (BOEC). Anat Rec 1995; 243: 347-56.

85 Desai N, Goldfarb J. Co-cultured human embryos may be subjected to widely different microenvironments: pattern of growth factor/cytokine release by Vero cells during the coculture interval. Hum Reprod 1998; 13: 1600-5.

86 Carnegie JA, Morgan JI, McDiarmid N, Durnford R. Influence of protein supplements on the secretion of leukaemia inhibitory factor by mitomycin-pretreated Vero cells: possible application to the in vitro production of bovine blastocysts with high cryotolerance. I Reprod Fertil 1999; 117: 41-8.

87 Fabbri R, Porcu E, Marsella T, Primavera MR, Cecconi S, Nottola SA, Motta PM, Venturoli S, Flamigni C. Human embryo development and pregnancies in an homologous granulosa cell coculture system. J Assist Reprod Genet 2000; 17: 1-12.

88 Olivennes F, Hazout A, Lelaidier C, Freitas S, Fanchin R, de Ziegler D, Frydman R. Four indications for embryo transfer at the blastocyst stage. Hum Reprod 1994; 9: 2367-73.

89 Bavister BD. Culture of preimplantation embryos: fact and artefact. Hum Reprod Update 1995; 1: $91-148$.

90 Zhao Y, Chegini N. Human fallopian tube expresses granulocyte-macrophage colony stimulating factor (GM-CSF) and GM-CSF alpha and beta receptors and contain immunoreactive GMCSF protein. J Clin Endocrinol Metab 1994; 79: 662-5.

91 Sjoblom C, Wikland M, Robertson SA. Granulocyte-macrophage colony-stimulating factor promotes human blastocyst development in vitro. Hum Reprod 1999; 14: 3069-76.

92 Robertson SA, Sjoblom C, Jasper MJ, Norman RJ, Seamark RF. Granulocyte-macrophage colony- 
stimulating factor promotes glucose transport and blastomere viability in murine preimplantation embryos. Biol Reprod 2001; 64: 1206-15.

93 Lee YL, Lee KF, Xu JS, Wang YL, Tsao SW, Yeung WS. Establishment and characterization of an immortalized human oviductal cell line. Mol Reprod Dev 2001; 59: 400-9.

94 Pfeifer TL, Chegini N. Immunohistochemical localization of insulin-like growth factor (IGF-I), IGF-I receptor, and IGF binding proteins 14 in human fallopian tube at various reproductive stages. Biol Reprod 1994; 50: 281-9.

95 Dunglison GF, Kaye PL. Insulin regulates protein metabolism in mouse blastocysts. Mol Reprod Dev 1993; 36: 42-8.

96 Martin KL, Barlow DH, Sargent IL. Heparin-binding epidermal growth factor significantly improves human blastocyst development and hatching in serum-free medium. Hum Reprod 1998; 13: 1645-52.

97 Hunter RH. Modulation of gamete and embryonic microenvironments by oviduct glycoproteins. Mol Reprod Dev 1994; 39: 176-81.

98 Lee KF, Chow JF, Xu JS, Chan ST, Ip SM, Yeung WS. A comparative study of gene expression in murine embryos developed in vivo, cultured in vitro, and cocultured with human oviductal cells using messenger ribonucleic acid differential display. Biol Reprod 2001; 64: 910-17.

99 Xu J, Cheung TM, Chan ST, Ho PC, Yeung WS. Human oviductal cells reduce the incidence of apoptosis in cocultured mouse embryos. Fertil Steril 2000; 74: 1215-19.

100 Xia P, Han VK, Viuff D, Armstrong DT, Watson AJ. Expression of insulin-like growth factors in two bovine oviductal cultures employed for embryo co-culture. J Endocrinol 1996; 149: 41-53.

101 Spanos S, Becker DL, Winston RM, Hardy K. Anti-apoptotic action of insulin-like growth factorI during human preimplantation embryo development. Biol Reprod 2000; 63: 1413-20.

102 Xu JS, Cheung TM, Chan ST, Ho PC, Yeung WS. Temporal effect of human oviductal cell and its derived embryotrophic factors on mouse embryo development. Biol Reprod 2001; 65: 1481-8.

103 Liu HC, He ZY, Mele CA, Veeck LL, Davis O, Rosenwaks Z. Human endometrial stromal cells improve embryo quality by enhancing the expression of insulin-like growth factors and their receptors in cocultured human preimplantation embryos. Fertil Steril 1999; 71:361-7.

104 Joo BS, Kim MK, Na YJ, Moon HS, Lee KS, Kim HD. The mechanism of action of coculture on embryo development in the mouse model: direct embryo-to-cell contact and the removal of deleterious components. Fertil Steril 2001; 75: 193-9.

105 Edwards LJ, Batt PA, Gandolfi F, Gardner DK. Modifications made to culture medium by bovine oviduct epithelial cells: changes to carbohydrates stimulate bovine embryo development. Mol Reprod Dev 1997; 46: 146-54.

106 Fukaya T, Chida S, Murakami T, Yajima A. Is direct cell-to-cell contact needed to improve embryonic development in co-culture? Tohoku J Exp Med 1996; 180: 225-32.

107 Barmat LI, Worrilow KC, Paynton BV. Growth factor expression by human oviduct and buffalo rat liver coculture cells. Fertil Steril 1997; 67: 775-9.

108 Lee YL, Xu JS, Chan ST, Ho PC, Yeung WS. Vero cells, but not oviductal cells, increase the hatching frequency and total cell count of mouse blastocysts partly by changing energy substrate concentrations in culture medium. I Assist Reprod Genet 2001; 18: 566-74.

109 Wiemer KE, Watson AJ, Polanski V, McKenna AI, Fick GH, Schultz GA. Effects of maturation and co-culture treatments on the developmental capacity of early bovine embryos. Mol Reprod Dev 1991; 30: 330-8.

110 Goff AK, Smith LC. Effect of steroid treatment of endometrial cells on blastocyst development during co-culture. Theriogenology 1998; 49: 1021-30.

111 Wetzels AM, Bastiaans BA, Hendriks JC, Goverde HJ, Punt-van der Zalm AP, Verbeet JG, Braat DD. The effects of co-culture with human fibroblasts on human embryo development in vitro and implantation. Hum Reprod 1998; 13: 1325-30.

112 Stein BA, O'Neill C. Morphometric evidence of changes in the vasculature of the uterine tube of mice induced by the 2-cell embryo on the second day of pregnancy. I Anat 1994; 185: 397-403. 
113 Ryan JP, Spinks NR, O'Neill C, Ammit AJ, Wales RG. Platelet activating factor (PAF) production by mouse embryos in vitro and its effect on embryonic metabolism. I Cell Biochem 1989; 40: 387-95.

114 Wells XE, O’Neill C. Biosynthesis of platelet-activating factor by two-cell mouse embryos. I Reprod Fertil 1992; 96: 61-71.

115 Battye KM, Ammit AJ, O'Neill C, Evans G. Production of platelet-activating factor by the preimplantation sheep embryo. J Reprod Fertil 1991; 93: 507-14.

116 O’Neill C, Gidley-Baird AA, Pike IL, Porter RN, Sinosich MJ, Saunders DM. Maternal blood platelet physiology and luteal-phase endocrinology as a means of monitoring pre- and postimplantation embryo viability following in vitro fertilization. I In Vitro Fertil Embryo Transf 1985; 2: 87-93.

117 O'Neill C. Embryo-derived platelet activating factor. Reprod Fertil Dev 1992; 4: 283-8.

118 Velasquez LA, Maisey K, Fernandez R, Valdes D, Cardenas H, Imarai M, Delgado J, Aguilera J, Croxatto HB. PAF receptor and PAF acetylhydrolase expression in the endosalpinx of the human Fallopian tube: possible role of embryo-derived PAF in the control of embryo transport to the uterus. Hum Reprod 2001; 16: 1583-7.

119 Tiemann U, Viergutz T, Jonas L, Wollenhaupt K, Pohland R, Kanitz W. Fluorometric detection of platelet activating factor receptor in cultured oviductal epithelial and stromal cells and endometrial stromal cells from bovine at different stages of the oestrous cycle and early pregnancy. Domest Anim Endocrinol 2001; 20: 149-64.

120 Downing SJ, Chambers EL, Maguiness SD, Watson A, Leese HJ. Effect of inflammatory mediators on the electrophysiology of the human oviduct. Biol Reprod 1999; 61: 657-64.

121 Tiemann U, Neels P, Kuchenmeister U, Walzel H, Spitschak M. Effect of ATP and plateletactivating factor on intracellular calcium concentrations of cultured oviductal cells from cows. $J$ Reprod Fertil 1996; 108: 1-9.

122 Tiemann U, Neels P, Pohland R, Walzel H, Lohrke B. Influence of inhibitors on increase in intracellular free calcium and proliferation induced by platelet-activating factor in bovine oviductal cells. J Reprod Fertil 1999; 116: 63-72.

123 Ortiz ME, Bedregal P, Carvajal MI, Croxatto HB. Fertilized and unfertilized ova are transported at different rates by the hamster oviduct. Biol Reprod 1986; 34: 777-81.

124 Ortiz ME, Llados C, Croxatto HB. Embryos of different ages transferred to the rat oviduct enter the uterus at different times. Biol Reprod 1989; 41: 381-4.

125 Rasweiler JJ. Differential transport of embryos and degenerating ova by the oviducts of the longtongued bat, Glossophaga soricina. J Reprod Fertil 1979; 55: 329-34.

126 Freeman DA, Woods GL, Vanderwall DK, Weber JA. Embryo-initiated oviductal transport in mares. J Reprod Fertil 1992; 95: 535-8.

127 Weber JA, Freeman DA, Vanderwall DK, Woods GL. Prostaglandin $E_{2}$ secretion by oviductal transport-stage equine embryos. Biol Reprod 1991; 45: 540-3.

128 Weber JA, Freeman DA, Vanderwall DK, Woods GL. Prostaglandin $E_{2}$ hastens oviductal transport of equine embryos. Biol Reprod 1991; 45: 544-6.

129 Velasquez LA, Aguilera JG, Croxatto HB. Possible role of platelet-activating factor in embryonic signaling during oviductal transport in the hamster. Biol Reprod 1995; 52: 1302-6.

130 Hermoso MA, Villalon MJ. Embryo secreted factors increase the frequency of ciliary beat of hamster oviduct cells in vitro. Biol Reprod 1995; 52 [Suppl 1]: 180.

131 Hermoso M, Barrera N, Morales B, Perez S, Villalon M. Platelet activating factor increases ciliary activity in the hamster oviduct through epithelial production of prostaglandin $\mathrm{E}_{2}$. Pflügers Arch 2001; 442: 336-45.

132 Chow JF, Lee KF, Chan ST, Yeung WS. Quantification of transforming growth factor betal (TGFbeta1) mRNA expression in mouse preimplantation embryos and determination of TGFbeta receptor (type I and type II) expression in mouse embryos and reproductive tract. Mol Hum Reprod 2001; 7: 1047-56. 
133 Wakuda K, Takakura K, Nakanishi K, Kita N, Shi H, Hirose M, Noda Y. Embryo-dependent induction of embryo receptivity in the mouse endometrium. J Reprod Fertil 1999; 115: 315-24.

$134 \mathrm{O}^{\prime} \mathrm{Neill} \mathrm{C}$. Examination of the causes of early pregnancy-associated thrombocytopenia in mice. $J$ Reprod Fertil 1985; 73: 567-77.

135 Liu HC, Mele C, Catz D, Noyes N, Rosenwaks Z. Production of insulin-like growth factor binding proteins (IGFBPs) by human endometrial stromal cell is stimulated by the presence of embryos. I Assist Reprod Genet 1995; 12: 78-87.

136 Lawitts JA, Biggers JD. Optimization of mouse embryo culture media using simplex methods. J Reprod Fertil 1991; 91: 543-56.

137 Biggers JD. Reflections on the culture of the preimplantation embryo. Int J Dev Biol 1998; 42: 879-84.

138 Bongso A, Fong CY, Ng SC, Ratnam S. The search for improved in-vitro systems should not be ignored: embryo co-culture may be one of them. Hum Reprod 1993; 8: 1155-60.

139 Bavister BD. Co-culture for embryo development: is it really necessary? Hum Reprod 1992; 7: 1339-41.

140 Leppens G, Sakkas D. Differential effect of epithelial cell-conditioned medium fractions on preimplantation mouse embryo development. Hum Reprod 1995; 10: 1178-83.

141 Jacobsen H, Schmidt M, Holm P, Sangild PT, Vajta G, Greve T, Callesen H. Body dimensions and birth and organ weights of calves derived from in vitro produced embryos cultured with or without serum and oviduct epithelium cells. Theriogenology 2000; 53: 1761-9.

142 Behboodi E, Anderson GB, BonDurant RH, Cargill SL, Kreuscher BR, Medrano JF, Murray JD. Birth of large calves that developed from in vitro-derived bovine embryos. Theriogenology 1995; 44: 229-32.

143 Pegoraro LM, Thuard JM, Delalleau N, Guerin B, Deschamps JC, Marquant LG, Humblot P. Comparison of sex ratio and cell number of IVM-IVF bovine blastocysts co-cultured with bovine oviduct epithelial cells or with Vero cells. Theriogenology 1998; 49: 1579-90.

144 Liu HC, He ZY, Tang YX, Mele CA, Veeck LL, Davis O, Rosenwaks Z. Simultaneous detection of multiple gene expression in mouse and human individual preimplantation embryos. Fertil Steril 1997; 67: 733-41.

145 Giudice LC, Dsupin BA, Irwin JC, Eckert RL. Identification of insulin-like growth factor binding proteins in human oviduct. Fertil Steril 1992; 57: 294-301.

146 Zhao Y, Chegini N, Flanders KC. Human fallopian tube expresses transforming growth factor (TGF beta) isoforms, TGF beta type IIII receptor messenger ribonucleic acid and protein, and contains [ ${ }^{125}$ I]TGF beta-binding sites. J Clin Endocrinol Metab 1994; 79: 1177-84.

147 Austgulen R, Arntzen KJ, Vatten LJ, Kahn J, Sunde A. Detection of cytokines (interleukin-1, interleukin-6, transforming growth factor-beta) and soluble tumour necrosis factor receptors in embryo culture fluids during in-vitro fertilization. Hum Reprod 1995; 10: 171-6.

148 Osterlund C, Fried G. TGFbeta receptor types I and II and the substrate proteins Smad 2 and 3 are present in human oocytes. Mol Hum Reprod 2000; 6: 498-503.

149 Ledger WL. Inhibins and activins during gamete and embryo transport, a comparative study. Gynecol Endocrinol 2001; 15 [Suppl 5]: 218.

150 He ZY, Liu HC, Mele CA, Barmat L, Veeck LL, Davis O, Rosenwaks Z. Expression of inhibin/ activin subunits and their receptors and binding proteins in human preimplantation embryos. $J$ Assist Reprod Genet 1999; 16: 73-80.

151 Chegini N, Zhao Y, McLean FW. Expression of messenger ribonucleic acid and presence of immunoreactive proteins for epidermal growth factor (EGF), transforming growth factor alpha (TGF alpha) and EGF/TGF-58.

152 el Danasouri I, Frances A, Westphal LM. Immunocytochemical localization of transforming growth factor-alpha and epidermal growth factor receptor in human fallopian tubes and cumulus cells. Am I Reprod Immunol 1993; 30: 82-7.

153 Lei ZM, Rao CV. Expression of epidermal growth factor (EGF) receptor and its ligands, EGF and transforming growth factor-alpha, in human fallopian tubes. Endocrinology 1992; 131: 947-57. 
154 Chia CM, Winston RM, Handyside AH. EGF, TGF-alpha and EGFR expression in human preimplantation embryos. Development 1995; 121: 299-307.

155 Krussel JS, Behr B, Milki AA, Hirchenhain J, Wen Y, Bielfeld P, Lake PM. Vascular endothelial growth factor (VEGF) mRNA splice variants are differentially expressed in human blastocysts. Mol Hum Reprod 2001; 7: 57-63.

156 Osterlund C, Wramsby H, Pousette A. Temporal expression of platelet-derived growth factor (PDGF)-A and its receptor in human preimplantation embryos. Mol Hum Reprod 1996; 2: 507-12.

157 Yeung WS, Lau EY, Chan AY, Ho PC. The production of interleukin-1 alpha immunoreactivity by human oviductal cells in a coculture system. J Assist Reprod Genet 1996; 13: 772-5.

158 Sheth KV, Roca GL, al Sedairy ST, Parhar RS, Hamilton CJ, al Abdul JF. Prediction of successful embryo implantation by measuring interleukin-1- alpha and immunosuppressive factor(s) in preimplantation embryo culture fluid. Fertil Steril 1991; 55: 952-7.

159 Srivastava MD, Lippes J, Srivastava BI. Cytokines of the human reproductive tract. Am J Reprod Immunol 1996; 36: 157-66.

160 Krussel JS, Simon C, Rubio MC, Pape AR, Wen Y, Huang HY, Bielfeld P, Polan ML. Expression of interleukin-1 system mRNA in single blastomeres from human preimplantation embryos. Hum Reprod 1998; 13: 2206-11.

161 los Santos MJ, Mercader A, Frances A, Portoles E, Remohi J, Pellicer A, Simon C. Role of endometrial factors in regulating secretion of components of the immunoreactive human embryonic interleukin-1 system during embryonic development. Biol Reprod 1996; 54: 563-74.

162 Sharkey AM, Dellow K, Blayney M, Macnamee M, Charnock-Jones S, Smith SK. Stage-specific expression of cytokine and receptor messenger ribonucleic acids in human preimplantation embryos. Biol Reprod 1995; 53: 974-81.

163 Zolti M, Ben Rafael Z, Meirom R, Shemesh M, Bider D, Mashiach S, Apte RN. Cytokine involvement in oocytes and early embryos. Fertil Steril 1991; 56: 265-72.

164 van Eijk MJ, Mandelbaum J, Salat-Baroux J, Belaisch-Allart J, Plachot M, Junca AM, Mummery CL. Expression of leukaemia inhibitory factor receptor subunits LIFR beta and gp130 in human oocytes and preimplantation embryos. Mol Hum Reprod 1996; 2: 355-60.

165 Charnock-Jones DS, Sharkey AM, Fenwick P, Smith SK. Leukaemia inhibitory factor mRNA concentration peaks in human endometrium at the time of implantation and the blastocyst contains mRNA for the receptor at this time. J Reprod Fertil 1994; 101: 421-6.

166 Tay JI, Rutherford AJ, Killick SR, Maguiness SD, Partridge RJ, Leese HJ. Human tubal fluid: production, nutrient composition and response to adrenergic agents. Hum Reprod 1997; 12: 2451-6.

167 Dickens CJ, Maguiness SD, Comer MT, Palmer A, Rutherford AJ, Leese HJ. Human tubal fluid: formation and composition during vascular perfusion of the fallopian tube. Hum Reprod 1995; 10: $505-8$.

168 Borland RM, Biggers JD, Lechene CP, Taymor ML. Elemental composition of fluid in the human Fallopian tube. J Reprod Fertil 1980; 58: 479-82.

169 Maas DH, Storey BT, Mastroianni L Jr. Oxygen tension in the oviduct of the rhesus monkey (Macaca mulatta). Fertil Steril 1976; 27: 1312-17.

170 Fischer B, Bavister BD. Oxygen tension in the oviduct and uterus of rhesus monkeys, hamsters and rabbits. J Reprod Fertil 1993; 99: 673-9.

171 Wiemer KE, Hoffman DI, Maxson WS, Eager S, Muhlberger B, Fiore I, Cuervo M. Embryonic morphology and rate of implantation of human embryos following co-culture on bovine oviductal epithelial cells. Hum Reprod 1993; 8: 97-101.

172 Morgan K, Wiemer K, Steuerwald N, Hoffman D, Maxson W, Godke R. Use of videocinematography to assess morphological qualities of conventionally cultured and cocultured embryos. Hum Reprod 1995; 10: 2371-6. 